\title{
IS SHOOTING A SPORT? THE OUTLINE OF SPORT SHOOTING IN POLAND AS A SUBJECT MATTER OF THE SOCIOLOGY OF SPORT
}

\begin{abstract}
The main goals of this text are to answer the question of whether sport shooting should be treated as a sport and to convince readers that shooting can be an interesting subject within the sociology of sport. Sport shooting is an activity that is dynamically developing and has engaged more and more people in recent years in Poland. The article presents the history and specificity of this sport discipline, including the presentation of the competition and the classification of people participating in the social world of shooters. The text also contains preliminary conclusions on social phenomena concerning the shooting environment and methodological considerations related to barriers occurring in the study of this environment.
\end{abstract}

Keywords: sport shooting, firearms, guns, social worlds, social practices, ethnography.

\section{Introduction}

The main goals of this text are to answer the question of whether sport shooting should be treated as a sport and to convince readers that shooting can be an interesting subject within the sociology of sport. In recent years, sport shooting has become increasingly popular and attracted many new shooters and amateurs of firearms around the world (and now also in Poland). This activity, as well as hunting and firearms collecting, allows civilians to obtain a gun permit (in this case, especially for a handgun, excluded from a hunter's permit). In order for a person to get involved in sport shooting, closely regulated specialist equipment is needed. The phenomenon of sport shooting therefore gives rise to a number of important questions, such as the shooter's motivation, which is not always related to fitness needs nor the spirit of rivalry. Sport shooting issues seem to be an interesting sociological theme, but in fact one might find them difficult to examine. Even though this sports discipline is available to almost everyone, the specific nature of

* MA, Institute of Sociology, Nicolaus Copernicus University in Toruń, ul. Fosa Staromiejska 1A, 87-100 Toruń, e-mail: piotradamzwarycz@gmail.com 
this activity makes shooters rather unseen. As they are allowed to practice only in a special separate area, namely a shooting range, for practical and legal reasons they do not reveal themselves publicly as gun owners. Shooters form a hermetic and exclusive community to which others have restricted access. It seems that the only possibility for examining this group is to observe it from the inside, taking on the role of a researcher-participant (Hammersley, Atkinson 2000).

The nature of the sport shooting community is best illustrated by the social worlds theory. First of all, shooters focus on the primary activity, which is "shooting", and subsequently engage in numerous activities and processes accompanying shooting. ${ }^{1}$

While pursuing its activities, the shooting community uses specialized technology: firearms in the form of pistols, shotguns and rifles. This technology is an inseparable element of the social world; it builds it and is the engine of its development (Strauss 1978). Weapons are also connected with the processes of professionalizing activities, which result in the development of players and the emergence of various types of specialized services provided to representatives of the social environment. People involved in the world of social shooters must acquire specific skills related to the use of weapons, especially regarding their own safety and that of other people nearby.

The borders of the social world (Strauss 1993) of shooters are especially interesting, since it is at them that participants answer questions about their identity and involvement in the social world. This is where the question in the title arises: "is shooting a sport?", or "when does it start to be a sport?". So you can wonder if and when the participant becomes an "athlete". The answer to these questions is also connected with building the identity of an individual participating in a given social world. Identity is related to acceptance and submission to group norms (Strauss 2013), so it is difficult to imagine a shooter who is also a pacifist that hates firearms, but it is no longer difficult to find a participant in the sports shooters sub-world who is vegan or opposed to hunting.

At the same time, it should be emphasized that the fact that people who practice shooting meet certain legal requirements and consider themselves athletes does not mean that shooting is a sport in the sociological context. It is worth considering whether sport shooting can be really classified and, consequently, analysed as a sport. In the past, shooting skills were useful for: 1) participating in military conflicts, 2) acquiring food (hunting), and 3) dispute resolution (duelling). Shooting practice had purely pragmatic dimension, far from the current understanding of the spirit of rivalry. A sporting activity, however, should fulfil the following functions (Wohl 1965: 140-141):

${ }^{1}$ Participation in the social life of shooting associations, competition in shooting competitions, participation in shooting training, physical development and analysis of the biomechanics of the body, building and maintenance of shooting ranges, promotion of shooting and gun culture, lobbying for a favorable interpretation of legal regulations, introducing technological innovations. 
1. Sport should be a form of distraction.

2. Sport should be spectacular.

3. Sport should form social bonds and social structures.

4. Sport should contribute to physical prowess.

According to Zbigniew Krawczyk (2011: 40), sport may be treated as a synonym for the term "physical culture", by which the author means "a relatively integrated and fixed system of the behaviours recognised by a community in the area of physical development, physical fitness, health, beauty, body perfection and personal expression, and the results of these behaviours".

Nowadays, sport shooting obviously includes elements of distraction or, more precisely, elements of recreation. This activity is reserved neither for law enforcement agencies nor for hunters. Sport shooting gathers its audience during competitions, and is also attractive for on-line results spotters. The spectacular nature of shooting is, however, limited for safety reasons, due to the specific nature of particular competitions. This sport is regulated by international federations, which lay down the detailed rules and procedures of shooting competitions and arrange rivalries at national and international levels. Sport shooting is practised by people of different ages and different levels of physical fitness who play the sport as members of local sport clubs. Training itself should not be limited to shooting at the shooting range, but it is the only place where people can really test their practical skills. Shooting sports, despite having a military-hunting tradition that reveals its pragmatic dimension, can now be regarded as a full-fledged sport activity.

The subject of firearms has been widely discussed by researchers, especially in the USA. ${ }^{2}$ An extensive literature review has shown that there is still no study strictly concerning sport shooting as a social phenomenon. This has been, and still is, an unexplored field, which is worth examining. Sport shooting, especially in the Polish scholarly literature (both sociological and sport science) has never been the subject of a real discussion. ${ }^{3}$

2 The main topics discussed by researchers are security (Hauser, Kleck 2013: 271-291; Lott 2013) and public health (Hemenway, Miller 2013: 2033-2035; Lewiecki, Miller 2013: 27-31), culture of gun ownership (Bellesiles 2000; Kalesan et al. 2017) and access of minors to firearms (Bilchik 2000; Brown 2004: 161-184).

3 The scholarly literature in Poland before 1989 focused mainly on two aspects of shooting: 1) on the military origin of shooting disciplines and the usefulness of shooting training in terms of national defense (Matuszak 1951: 628; 1952: 534-539; Szewczyk 1965: 500) and 2) shooting techniques within static disciplines (Matuszak 1957: 31-37; Janota 1958a: 16-22; 1958b: 111-119; Naglak, Zarzycki 1976: 211-214; Duda, Szczepański 1976: 268-271). After 1989, several advisory publications appeared, including: 1) basics of shooting training (Ca mp bel1 2014; Dougherty 2014; Podowski 2019), 2) basics of ballistics (Ejsmont 2011) and specialized publications of the Polish Association of Sport Shooting regarding: 1) the work of a shooting instructor (Kurzawski, Filipkowski 2007; Wodnik 2007; Kurzawski 2009; 2010; Kijowski 2013; Budnik-Przybylska, Staniszewski 2018), 2) health issues of shooters (Zgorski, Tkaczuk 2005: 99-107; Skrzypiec-Spring et al. 2009) 3) organization of sporting 
The term "shooting" used in this article denotes firearms ${ }^{4}$ activities. The author intentionally omitted activities such as archery, crossbow and airguns. In Poland, a bow and arrow as well as airguns can be legally possessed without permission, and these sports have a different character. In contrast to sport shooting, airguns and archery are not restricted by law, so they can be practiced in any safe place (not necessarily in shooting ranges). In addition, they are more open to new participants. It is different matter for crossbows in Poland. In this case, legal regulations are complicated, and it is really difficult to get permission to own a crossbow. As a consequence, this sport does not belong among the most popular ones.

The development of sport shooting strongly depends on national legislation. Firstly, it is through the legislature that the definition of firearms and the questions of additional permissions are laid down. Secondly, a decision as to who, and under what conditions, can apply for a gun permission also depends on the legislature. The next issue is the strong regulation of the number of firearms which a person is allowed to possess. Moreover, the legislature determines how to store firearms, how to travel with them, and where to use them, in accordance with the objective of the gun permission.

The strong dependence of sport shooting on legal regulation probably has its source in the state monopoly on the legitimate use of violence (Weber 1998). The legitimate use of violence is reserved for law enforcement agencies and military service. The state very reluctantly shares it with citizens. It should be noted that sport shooters use the same firearms as enforcers of state services (excluding automatic firearms, which are strictly restricted in the case of civilians). A well-organised and institutionalised sport shooting community with a variety of firearms and a stockpile of ammunition could contribute to the disruption of such a state monopoly-based order.

The first part of this article is devoted to the history of shooting on a global scale. The second part contains reflections on its institutionalisation in Poland. The next part of the article presents quantitative data on the development of sport shooting in Poland. The text closes with a presentation of the characteristics of sport shooting, based on the conclusions of preliminary observations obtained during field research of the shooting environment. ${ }^{5}$

competitions (Kurzawski 2009; Mauer-Różańska 2018), 4) the use of new technologies in shooting sports (Gładyszewski et al. 2005).

${ }^{4}$ The legal definition of firearms is contained in the Polish Firearms Act form 21 May 1999. According to the law, firearms are portable barrel devices that launch, are designed to be fired or can be adapted to shoot one or more bullets or substances as a result of the action of the propellant.

5 The field study of the sports shooter community has been carried out by the author since June 2019. It is planned to cover approximately 20 individual in-depth interviews, 15 participant observations and long-term participant observation of shooting ranges. The respondents are people who own firearms (sport shooters, collectors, hunters, etc.), who practice shooting sports, and run shooting ranges and companies operating in the shooting industry. Shooting competitions, shooting picnics, thematic events (children's day, November 11, father's day, etc.) are subject to participating observations. 


\section{Sport shooting in the context of world history}

Sport shooting's origins date back to the 15-16th centuries. The oldest preserved historical record of this activity is found in Swiss drawings made in 1504. Hunting and sport shooting were a symbol of high social status among the British aristocracy (Martin 2012).

Sport shooting has been an Olympic discipline since the 1896 Summer Olympics held in Athens. The shooting competitions that were held then were static ones: the competitors were standing in front of bullseye targets (bullseye shooting). At the 1906 Summer Olympics (also called the 1906 Intercalated Games, organised on the occasion of the 10th anniversary of the first modern Olympic Games, not included in the Olympic medal counts) the competition was extended with the inclusion of pistol duelling. This corresponded to 18th-century traditional fights with pistols, but in its modern version wax bulls, instead of the lead ones, were used. This competition, however, was held only once, then repeated two years later in London, just as a spectacle.

One of the most significant moments was when on the 17th of July 1907 the International Shooting Union was established in Zurich (the current name, International Shooting Sport Federation, was adapted in 1998). Its founders were Austria, Belgium, France, Greece, Italy, the Netherlands and Argentina (IS SF 2020). The membership of the ISSF consists of national shooting associations which are independent control authorities responsible for issues associated with amateur shooting in a given country. Representing 161 of these, the ISSF is a member of the International Olympic Committee.

The subsequent development of sport shooting was influenced by a significant change in American military service trainings. The analysis of situations in which the officers had to use firearms led to the conclusion that static training at the shooting range was not sufficient. To give officers the ability to use firearms in dynamically changing situations, practical scenario-based shooting trainings were introduced. In the 1950s, the representatives of the American military took part in annual shooting competitions, during which they had a chance to share their experiences and to compare different shooting techniques. Practical shooting became so popular that during a conference in Columbia, Missouri in 1976, a group of enthusiasts established the International Practical Shooting Confederation (IPSC) and, therefore, officially declared the discipline an international sport designed for both uniformed services and civilians. Over time, IPSC, came to denote the discipline itself (it took over the name from the confederation) and become a competitive sport, one that requires players to improve their shooting skills, and one that promotes the development of firearm production.

As a result of the fact that dynamic (practical) shooting changed its status, in 1996 a new federation was established. The formation of the International Defensive Pistol Association (IDPA) was actually the result of a split caused by the 
shooters who were not enthusiastic about the course of practical shooting's evolution. Firstly, they did not support the resignation to an exclusively defensive character of the discipline. Secondly, they opposed reducing the use of factory produced firearms in favour of individually adjusted and remade models.

\section{The development of sport shooting in Poland}

Before 2011, sport shooting was a niche discipline in Poland, even though Polish shooters have won 12 Olympic medals (PZSS 2020). This state of affairs may have stemmed from the legal situation at that time, in which the police administrative organs could authorise gun permission just under administrative recognition, with no regard for any precise legal provisions. The New Firearms Act of 2011 has removed the rule of administrative recognition for all types of gun permissions, excluding self-defence gun permission. Due to this change, Polish citizens have gained a real possibility to apply for possession of firearms after fulfilling all the requirements. Anyone who wants to get permission for a gun for sport shooting should join any sport shooting association, get a confirmation (passed examination) of his or her shooting skills (pol. patent strzelecki) and obtain the PZSS sport licence. If an applicant fulfils the above conditions, provides medical and psychological assessments, and is completely free from any other negative conditions, the police authority will be obliged to issue him or her a gun permission.

Since 2014, the police have collected data about the number of gun permissions issued and firearms registered.

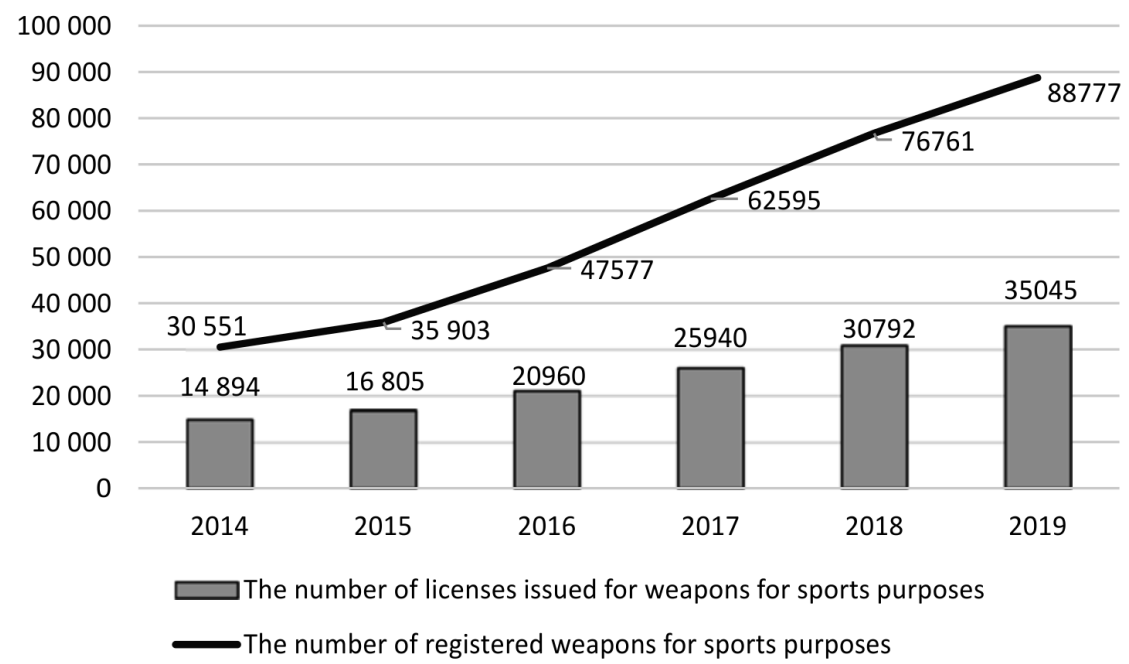

Chart 1. The number of sport shooting permissions issued, and firearms registered, from 2014 to 2019 Source: The author's own study, based on statistics provided by the Polish Police. 
Chart 1 . shows a stable increase in the number of sport shooting gun permissions from 2014 to 2019. In those years, gun permissions were issued for between 4,000 and 5,000 people. The number of sport shooters with gun permissions grew by approximately $135 \%$.

At the same time, the number of registered sport firearms also grew. There were 30,551 sport firearms registered in 2014 (which means 2.05 pieces for 1 gun permission). This number rose to 88,777 at the end of 2019 (2.53 pieces for 1 gun permission). This is approximately a $190 \%$ growth in sport firearms possession in the 5-year period. This data shows that sport shooting in Poland has been progressively gaining in popularity. The growing number of people interested in shooting has resulted in the increasing interest in new firearms. This market is developing dynamically, and sport shooters buy a few thousand firearms every year.

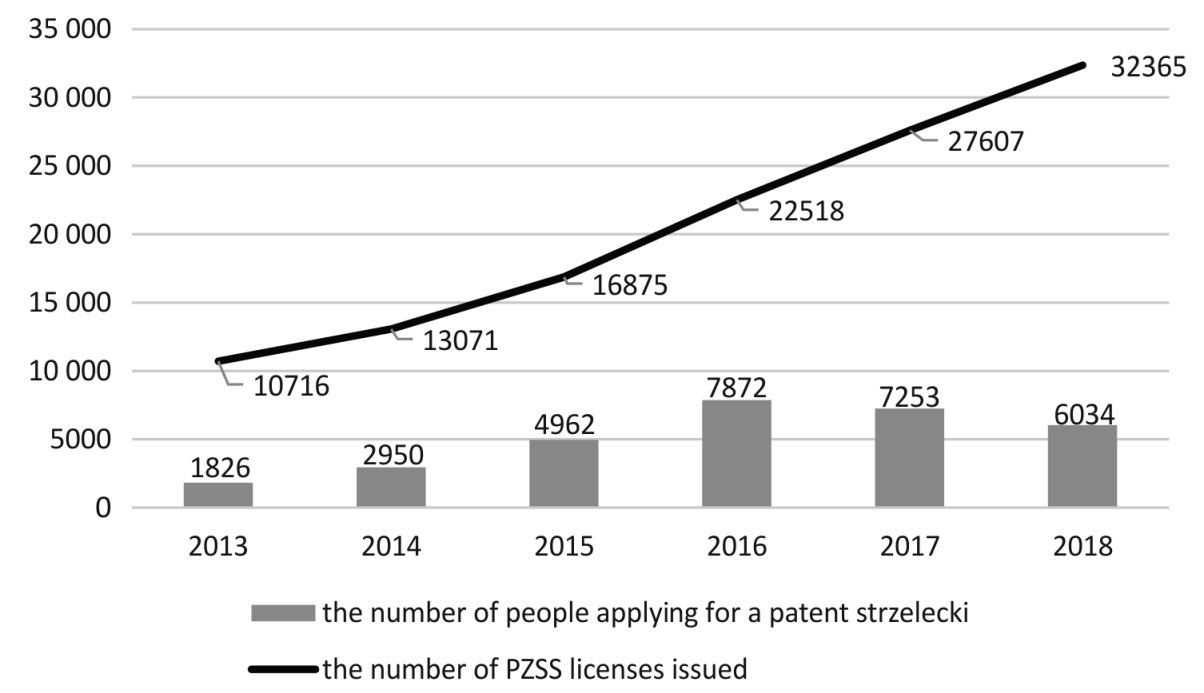

Chart 2. The number of PZSS sport licences and the number of individuals taking the competence exams

Source: The author's own study, based on PZSS annual reports.

Chart 2. shows even more clearly how sport shooting has been developing in Poland - it shows the number of PZSS sport licences and the number of individuals taking the competence exams (considering that not everybody pass the exams). It should be emphasised that not every person who has a PZSS license and who practices shooting has to apply for a gun permit. However, as a rule, players prefer to shoot with their private firearms, not the club ones. Sometimes, for economic reasons, they apply for permission long after receiving their documents from PZSS. As Chart 2. shows, between 3,000 and 6,000 people are issued with a sports license every year. Moreover, every year, a few thousand people take the exam, which certifies the acquisition of basic competences related to the use 
of firearms and entitles them to apply for the PZSS sports license. From 2013 to 2018, the number of sport shooters with the PZSS licenses increased by approximately $202 \%$.

According to the portal www.gdziestrzelac.eu, there are 452 civilian shooting ranges operating in Poland: commercial, sport, hunting and chanterelles (2020). ${ }^{6}$ In fact, there may be even more of these objects because they are not all registered, even though the portal is constantly being updated. For comparison, as part of the project "Moje Boisko - Orlik 2012", 2,604 facilities were built with the support of the state for almost PLN 970 million (NIK 2017: 5).

The portal www.gdziestrzelać.eu reports that there are also 254 stores designed for shooters, both sportsmen and hunters, and 49 gunsmiths' points in Poland, where weapons can be repaired or converted (2020). In addition, the above portal indicates that at least 110 training companies also operate on the market, and the statistics of the Polish Police indicate that at the end of 2019, 732 firearms licenses were issued for training purposes. These companies offer their services in the field of learning how to shoot and improve shooting competences, not only to representatives of law enforcement and security agencies, but also to sportsmen, people interested in defensive shooting, as well as Sunday shooters and people taking their first steps in shooting. In addition to numerous shooting training sessions, every week in Poland a few sports events, local and nationwide, are organised at clubs within the PZSS. Polish shooters are increasingly appearing at international events not only in Europe, but also in the US and Asia.

Due to increased interest in shooting, the firearms market in Poland is growing. Weapon users register about 40,000-50,000 new guns every year, buy ammunition for them (the amount of ammunition sold is impossible to estimate), along with numerous accessories, clothes, etc.

\section{An attempt at a sociological characterization of sport shooting in Poland}

Sport shooting may be interesting not only as a physical activity, but also as a social phenomenon. As the statistics show, the number of sport shooters in Poland is growing, and the question therefore arises: who are the people getting involved in shooting? Who are the people striving to possess firearms, learning how to use them and improve their shooting skills (and do they really improve them?)?

It should be noted that shooting is a fairly expensive sport, due to the high price of equipment, accessories and ammunition. In order to enter the environment, every shooter has to spend time and money to obtain the relevant documents

\footnotetext{
${ }^{6}$ https://gdziestrzelac.eu/mapa-strzelnic/ (accessed 15.05.2020).

7 Ibidem.
} 
and permissions for weapons - sport shooting has a high financial barrier to entry. ${ }^{8}$ The economic barrier and additional restrictions in the form of no criminal record and adequate health, including mental health, entail the social filtering of participants. However, it is possible to try shooting, especially in recreational form, without meeting all of these requirements. Anyone can come to the shooting range and, under the watchful eye of an instructor, pick up a firearm and shoot at a target.

Along with the increasing popularity of shooting, consideration should be given to the progressive professionalization and institutionalization of this sport. Due to the level of application and motivation, several groups of shooters can be distinguished:

1) Professionals - people for whom shooting in a source of income, who are employed by sports clubs or the army, or who are or supported by sponsors; professional players who use the training and competition service, trainers, instructors, owners of training companies.

2) Amateur-professionals - people deeply involved in shooting who train to achieve high results in competitions, but do not earn money from shooting, obtaining their main income in other industries, but who are sometimes covered by sponsorship (most often companies from the shooting industry).

3) "Carriers" - people whose main goal is to possess firearms and to walk around with them on a daily basis, participating in a minimum number of competitions so as to maintain a sports license; sport plays only a supporting role for them.

4) Idealists - people less associated with the sport itself, and more with the movement for the promotion of shooting and access to firearms.

5) Recreational shooters (hobbyists) - people who have no sporting aspirations and are interested in the subject of weapons and shooting, who often do not have a permit for a weapon, and if they have one, they treat the sport similarly to "carriers".

Despite the above division, determining the motivation to shoot and possess firearms requires further research. The basic motivations for shooting are: a desire to compete, integration with friends, communication of one's material status, the desire to possess a weapon, and a sense of danger and the related lack of confidence in public institutions.

The shooting environment is highly diversified, not only because of the purpose of owning a firearm, but also because of the sports competitions that are practiced. This is related to the use of different types of weapons in competition, different rules related to the course of competition and the counting of points, as well as the approach to individually modifying the weapons used. One of the links that connects all sport shooters is safety culture, which manifests itself in

${ }^{8}$ The basic cost of obtaining of gun permission is aprox. PLN 1,200-1,500. Additionally gun owners have to buy a certified valut for firearms storage, it costs next aprox. PLN 800-2,500. 
treating each weapon as potentially charged and ready to use. Each weapon is checked when passed between competitors and after sport competition. Unsafe use of a weapon or uncontrolled firing (even in a safe direction) is considered the worst offense and will be punished by disqualification.

PZSS allows shooting competitions to be organized in the following disciplines:

1) sport shooting (based on ISSF regulations),

2) long distance shooting (based on WBSF regulations),

3) black powder shooting (based on MLAIC regulations),

4) historical shooting (based on the provisions of the chanterelles),

5) dynamic shooting (based on the IPSC and IDPA regulations),

6) western shooting (based on the SASS regulations).

On the basis of the above, the first division of shooting sports into Olympic and non-Olympic disciplines can be outlined. This division is flawed because the schedule of Olympic disciplines is mobile and in subsequent Olympic periods there may be a migration of disciplines between the two indicated groups.

The second division proposed by PZSS, related to the issue of shooting patents and sport licenses, is based on the establishment of three sports: pistol, rifle, shotgun. From the point of view of clubs functioning and the sports licence system, it is a kind of facilitation, however, it causes problems e.g. in qualifying multidefence competitions. This division also does not highlight the specific nature of individual sports competitions, but only reduces them to the type of weapon used.

The next division of sports shooting into static, dynamic and athletics seems to be more accurate, because it is based on technical aspects related to each of these sports. Table 1 . shows the division of sport shooting disciplines which are played in Poland.

Table 1. The division of shooting disciplines in Poland

\begin{tabular}{|c|c|c|c|c|c|}
\hline \multicolumn{6}{|c|}{ Static shooting } \\
\hline $\begin{array}{c}\text { Type of } \\
\text { discipline }\end{array}$ & Type of firearms & Distance & $\begin{array}{c}\text { Type } \\
\text { of targets }\end{array}$ & Punctation & Comments \\
\hline 1 & 2 & 3 & 4 & 5 & 6 \\
\hline $\begin{array}{c}\text { Pistol } \\
\text { bullseye } \\
\text { shooting }\end{array}$ & $\begin{array}{c}\text { Rimfire } \\
\text { \& centrefire pistols }\end{array}$ & $\begin{array}{l}25 \mathrm{~m} \\
50 \mathrm{~m}\end{array}$ & $\begin{array}{l}\text { Bullseye } \\
\text { targets }\end{array}$ & $0-10$ & $\begin{array}{l}\text { accuracy to } \\
0.1 \text { in rimfire } \\
\text { competitions } \\
(\max .10,9)\end{array}$ \\
\hline $\begin{array}{l}\text { Carabine } \\
\text { bullseye } \\
\text { shooting }\end{array}$ & $\begin{array}{c}\text { Rimfire } \\
\& \text { centrefire } \\
\text { carabines }\end{array}$ & $\begin{array}{l}50 \mathrm{~m} \\
100 \mathrm{~m} \\
300 \mathrm{~m}\end{array}$ & $\begin{array}{c}\text { Bullseye } \\
\text { targets }\end{array}$ & $0-10$ & $\begin{array}{l}\text { accuracy to } \\
0.1 \text { in rimfire } \\
\text { competitions } \\
(\max .10,9)\end{array}$ \\
\hline
\end{tabular}


Is shooting a sport? The outline of sport shooting in Poland...

\begin{tabular}{|c|c|c|c|c|c|}
\hline 1 & 2 & 3 & 4 & 5 & 6 \\
\hline $\begin{array}{l}\text { Rapid fire } \\
\text { pistol }\end{array}$ & Rimfire pistols & $25 \mathrm{~m}$ & $\begin{array}{l}\text { Computer- } \\
\text { assisted } \\
\text { black circle } \\
\text { targets }\end{array}$ & $0-1$ & \\
\hline $\begin{array}{l}\text { Long range } \\
\text { shooting }\end{array}$ & $\begin{array}{l}\text { Centrefire cara- } \\
\text { bines }\end{array}$ & $\begin{array}{c}300 \mathrm{~m} \\
600 \mathrm{~m} \\
800 \mathrm{~m} \\
1000+\mathrm{yd} / \mathrm{m}\end{array}$ & $\begin{array}{l}\text { Bullseye } \\
\text { targets }\end{array}$ & $0-10$ & $\begin{array}{l}\text { the carabine is } \\
\text { based on bipod }\end{array}$ \\
\hline Benchrest & $\begin{array}{l}\text { Rimfire \& centre- } \\
\text { fire carabines }\end{array}$ & $\begin{array}{l}100 \mathrm{yd} / \mathrm{m} \\
200 \mathrm{yd} / \mathrm{m}\end{array}$ & $\begin{array}{l}20 \text { or } 25 \\
\text { circle } \\
\text { targets }\end{array}$ & $0-1$ & $\begin{array}{l}\text { the carabine is } \\
\text { based on special } \\
\text { bench and stand }\end{array}$ \\
\hline $\begin{array}{l}\text { SKEET/ } \\
\text { TRAP }\end{array}$ & Shotguns & - & Clay targets & $0-1$ & $\begin{array}{c}\text { the clays are } \\
\text { thrown by } \\
\text { a special machine } \\
\text { and shooted down } \\
\text { in flight }\end{array}$ \\
\hline $\begin{array}{l}\text { Moving } \\
\text { targets }\end{array}$ & $\begin{array}{l}\text { Shotguns } \\
\& \text { centrefire } \\
\text { carabines }\end{array}$ & $\begin{array}{l}35 \mathrm{~m} \\
50 \mathrm{~m} \\
100 \mathrm{~m}\end{array}$ & $\begin{array}{c}\text { Clay targets } \\
\text { \& carton } \\
\text { targets }\end{array}$ & $0-1 \& 0-10$ & $\begin{array}{c}\text { disciplines } \\
\text { popular among } \\
\text { hunters }\end{array}$ \\
\hline $\begin{array}{c}\text { Black } \\
\text { powder } \\
\text { shooting }\end{array}$ & $\begin{array}{l}\text { Black powder } \\
\text { handguns } \\
\& \text { carabines }\end{array}$ & $\begin{array}{l}25 \mathrm{~m} \\
50 \mathrm{~m} \\
100 \mathrm{~m}\end{array}$ & $\begin{array}{l}\text { Bullseye } \\
\text { targets }\end{array}$ & $0-10$ & \\
\hline \multicolumn{6}{|c|}{ Practical shooting (dynamic) } \\
\hline IPSC & $\begin{array}{l}\text { Rimfire and } \\
\text { centrefire pistols } \\
\text { and carabines, } \\
\text { shotguns, pistols } \\
\text { calibre carabine } \\
\text { (PCC) }\end{array}$ & $\begin{array}{l}\text { dependent } \\
\text { on } \\
\text { possibilities } \\
\text { of range }\end{array}$ & $\begin{array}{l}\text { carton and } \\
\text { steel targets }\end{array}$ & $\begin{array}{l}\text { Time/point } \\
\text { factor }\end{array}$ & \\
\hline IDPA & $\begin{array}{l}\text { Centrefire hand- } \\
\text { guns }\end{array}$ & up to $15 \mathrm{yd}$ & $\begin{array}{c}\text { carton and } \\
\text { steel targets }\end{array}$ & $\begin{array}{l}\text { Time with } \\
\text { time penalties }\end{array}$ & $\begin{array}{l}\text { Sport based on } \\
\text { self-defence } \\
\text { scenarios }\end{array}$ \\
\hline PIRO & $\begin{array}{l}\text { Centrefire hand- } \\
\text { guns }\end{array}$ & $\begin{array}{l}\text { up to } 30 \mathrm{~m} \\
\text { most up to } \\
15 \mathrm{~m}\end{array}$ & $\begin{array}{c}\text { carton and } \\
\text { steel targets }\end{array}$ & $\begin{array}{l}\text { Time with } \\
\text { time penalties }\end{array}$ & $\begin{array}{c}\text { Polish } \\
\text { modification of } \\
\text { IDPA rules }\end{array}$ \\
\hline Multigun & $\begin{array}{c}\text { Centrefire pistols, } \\
\text { carabines and } \\
\text { shotguns }\end{array}$ & $\begin{array}{l}\text { dependent } \\
\text { on } \\
\text { possibilities } \\
\text { of range }\end{array}$ & $\begin{array}{l}\text { carton } \\
\text { and metal } \\
\text { targets }\end{array}$ & $\begin{array}{l}\text { Time/point } \\
\text { factor or time } \\
\text { with time } \\
\text { penalties }\end{array}$ & $\begin{array}{c}\text { Most popular } \\
\text { 3GUN } \\
\text { (pistol+carabine } \\
\text { +shotgun) }\end{array}$ \\
\hline
\end{tabular}


Table 1. (cont.)

\begin{tabular}{|c|c|c|c|c|c|}
\hline 1 & 2 & 3 & 4 & 5 & 6 \\
\hline $\begin{array}{r}\text { Tactical } \\
\text { shooting }\end{array}$ & $\begin{array}{l}\text { Centrefire cara- } \\
\text { bines }\end{array}$ & $\begin{array}{l}\text { dependent } \\
\text { on } \\
\text { possibilities } \\
\text { of range }\end{array}$ & $\begin{array}{l}\text { various } \\
\text { targets }\end{array}$ & $\begin{array}{l}\text { Addicted to } \\
\text { competition's } \\
\text { rules }\end{array}$ & $\begin{array}{c}\text { simulating } \\
\text { a battlefield } \\
\text { situation and } \\
\text { practical scenarios }\end{array}$ \\
\hline $\begin{array}{c}\text { Steel } \\
\text { challenge }\end{array}$ & $\begin{array}{l}\text { Centrefire pistols } \\
\text { and shotguns }\end{array}$ & up to $20 \mathrm{~m}$ & $\begin{array}{l}5 \text { steel } \\
\text { targets }\end{array}$ & Time & \\
\hline $\begin{array}{l}\text { Western } \\
\text { shooting }\end{array}$ & $\begin{array}{l}\text { Black powder } \\
\text { handguns \& } \\
\text { carabines }\end{array}$ & $\begin{array}{l}\text { dependent } \\
\text { on } \\
\text { possibilities } \\
\text { of range }\end{array}$ & $\begin{array}{l}\text { carton and } \\
\text { steel targets }\end{array}$ & $\begin{array}{l}\text { Time with } \\
\text { time penalties }\end{array}$ & $\begin{array}{l}\text { combination } \\
\text { of sport and } \\
\text { historical } \\
\text { reconstruction } \\
\text { (shooters change } \\
\text { into western } \\
\text { outfits) }\end{array}$ \\
\hline \multicolumn{6}{|c|}{ Athletic shooting } \\
\hline Biathlon & Rimfire carabines & $50 \mathrm{~m}$ & $\begin{array}{l}5 \text { steel } \\
\text { targets }\end{array}$ & $\begin{array}{l}\text { Penalty time } \\
\text { or penalty lap } \\
\text { after miss }\end{array}$ & $\begin{array}{l}\text { Winter sport on } \\
\text { skies }\end{array}$ \\
\hline $\begin{array}{l}\text { Target } \\
\text { sprint }\end{array}$ & $\begin{array}{l}\text { According to } \\
\text { competition rules }\end{array}$ & $50 \mathrm{~m}$ & $\begin{array}{l}5 \text { steel } \\
\text { targets }\end{array}$ & & $\begin{array}{l}\text { Summer type of } \\
\text { biathlon, running } \\
\text { or rollers }\end{array}$ \\
\hline $\begin{array}{c}\text { Bike } \\
\text { biathlon }\end{array}$ & $\begin{array}{l}\text { According to } \\
\text { competition rules }\end{array}$ & $50 \mathrm{~m}$ & $\begin{array}{l}5 \text { steel } \\
\text { targets }\end{array}$ & & $\begin{array}{l}\text { Summer type of } \\
\text { biathlon, cycling }\end{array}$ \\
\hline
\end{tabular}

Source: The author's own study.

Shooting is a stigmatized activity due to the fact that use of firearms is associated with warfare, law enforcement agencies and hunting. The sport shooters' being distinguished from hunters is particularly noticeable. Being a hunter has more to do with professional work than recreation, even one year's internship as a hunter is like being trained. Athletes must also take an internship at the club before taking the exam, but it is purely sports-related and prepares for further competition. Sport shooters distinguish themselves from hunters and from the ethical stigma associated with killing animals that is accompanied by a cult of tradition and hunting economy. The stigmatisation of shooting means that a large group of shooters do not publicly admit to this activity. Even despite the participation of politicians, businessmen, lawyers and representatives of local elites, the subject of shooting has no political legitimacy or representation. It can even be said that shooting, as an uncomfortable subject, is politically censored. The development of shooting is strongly dependent on the ties within the social environment and the financial and organisational capabilities of its participants, as well as the support of the business that is favourable to it (often thematically related to shooting). 
As shooting develops, its internal institutionalisation progresses. This is associated not only with the external dependence of sport shooting on the police authorities and the PZSS in the terms of issuing permits, but also with the internal processes associated with the professionalisation of this sport. More and more sport clubs that associate shooters are being created, which is interesting, because there are clubs that do not have their own shooting ranges, and yet they gather members and animate sport activities. The growing interest in shooting determines the emergence of specialised companies that develop the market and try to use the financial commitment of participants. One of the pillars of the shooting market are institutions, including law firms, that have specialised in conducting administrative proceedings in the area of issuing licenses for firearms (the entire procedure lasts from 2 to 6 months). There are more and more specialised stores with arms and ammunition, as well as entrepreneurs who in a relatively short time are able to import weapons or parts from abroad, including the United States. In addition to shooting, there are also many businesses supporting shooters: gunsmiths, training companies and manufacturers of numerous accessories useful during sports competition.

Sport shooting has been greatly commercialised in recent years - sports clubs and private shooting ranges are aware of access to firearms, i.e. goods that are heavily regulated by the state. Firearms strongly influence consumer emotions and for many groups they are the object of desire. Therefore, the shooting community organises numerous open events in the form of family shooting picnics, where you can see numerous copies of modern and historical weapons, as well as shoot with them for a fee. It is becoming more and more fashionable to organize stag and hen parties at shooting ranges as an introduction to further fun in the city. Vouchers and gift cards, which can be purchased at the shooting range and given to family members or friends for birthdays or Christmas, are also gaining in popularity. It is also common practice to organise company integration events at shooting ranges, which not only allow employers to strengthen ties between employees, but also can help them discover hidden talents. Shooting ranges are also becoming a place for informal business meetings, where you can take a valuable contractor to plan or celebrate cooperation in the professional field.

In addition to the phenomena described above, shooting is also associated with a number of other social phenomena. For example, the contact of the shooting environment with preppers, or phenomena regarding firearms that took place in connection with the COVID-19 epidemic (gunpowder and ammunition disappeared from store shelves, the sale of private weapons froze, but the rise in speculation on prices of black powder weapons, which practically ceased to be available in stationary and online stores), seem to be worth researching. 


\section{Conclusions}

Answering the question in the title, I conclude that sport shooting is a sport in the context of the sociology of sport. It is a very diverse sport. It is at the same time a social world, and more precisely a new and dynamically developing subworld, for the social world of shooters as a whole.

Sport shooting should be considered a sport because it is a form of social activity that can be a form of recreation or entertainment. At the same time, it is an activity that is spectacular, and more and more participants treat it as a competitive activity and develop physically in order to obtain better and better results. Moreover, sport shooting, by concentrating its activity around sports associations, on the one hand creates complex structures governing this form of physical activity, and on the other hand it connects players, causing the formation of social networks and strengthening social bonds.

The issues associated with sport shooting cannot be reduced to issues related to access to firearms and the rules of organization of sport competitions. There are many interesting sociological phenomena connected to sport shooting. Among these, it is worth paying attention primarily to:

1) the progressive professionalization of this sport,

2) the institutionalization of the environment,

3) the internal diversity of the environment,

4) the development of sponsorship,

5) the development of trade and services related to shooting,

6) the motivations and social practices of participants.

Studying the issues related to shooting involves overcoming many barriers. The social world of shooters and its individual sub-worlds have a closed, non-public character. Shooting activities are concentrated around institutionalized shooting clubs and semi-open sports facilities - shooting ranges. Entering this social world is associated with high costs, both in financial terms and with regard to the time spent on acquiring appropriate knowledge and qualifications. Shooting is also associated with a kind of stigma, as it is a social group that has access to technologies equated with force and violence. The isolation of the shooting environment causes many methodological problems that must be dealt with by the researcher of this issue. Participants are not very sympathetic to sharing knowledge about social practices with outsiders (observers), so the researcher should become a participant in these practices. This is connected with the need to acquire new knowledge, practical skills, as well as acquiring the sociolect characteristic of the group.

\section{Bibliography}

Bellesiles M. (2000), Arming America. The Origins of a National Gun Culture, Alfred A. Knopf, Brooklyn. 
Bilchik S. (2000), Kids and Guns, U.S. Department of Justice, Washington DC.

Brown B. (2004), Juveniles and Weapons: Recent Research. Conceptual Considerations, and Programmatic Interventions, "Youth Violence and Juvenile Justice", vol. 2(2), pp. 161-184.

Budnik-Przybylska D., Staniszewski C. (2018), Doskonalenie koncentracji uwagi w przygotowaniu zawodnika strzelectwa sportowego, "Strzelectwo sportowe (Nowoczesne rozwiązania szkoleniowe)", no. 15, Wrocław, pp. 81-86.

Campbell R. (2014), Strzelanie z broni palnej, transl. M. Daniel, Wiedza Powszechna, Warszawa.

Dougherty M. (2014), Broń sportowa, transl. T. Prochenka, M. Wasilewski, Bellona, Warszawa.

Duda J., Szczepański S. (1976), Problemy naboru i selekcji w strzelaniu z broni długiej, "Kultura Fizyczna", no. 5, pp. 268-271.

Ejsmont J.A. (2011), Balistyka dla snajperów, Wydawnictwo Naukowe PWN, Warszawa.

gdziestrzelac.eu (2020), Mapa strzelnic, https:/gdziestrzelac.eu/mapa-strzelnic/ (accessed 15.05.2020).

Gładyszewski G., Chocyk D., Uciński T., Gładyszewska B. (2005), Informatyka i elektronika $w$ strzelectwie sportowym, "Strzelectwo sportowe (Nowoczesne rozwiązania szkoleniowe)", no. 2, Wrocław, pp. 45-53.

Hammersley M., Atkinson P. (2000), Metody badań terenowych, transl. S. Dymczyk, Zysk i S-ka, Poznań.

Hauser W., Kleck G. (2013), Guns and Fear A One-Way Street?, "Crime \& Delinquency", vol. 59(2), pp. 271-291.

Hemenway D., Miller M. (2013), Public Health Approach to the Prevention of Gun Violence, "The New England Journal of Medicine", no. 368, pp. 2033-2035.

International Shooting Sport Federation (ISSF) (2020), The ISSF history, https://www. issf-sports.org/theissf/history.ashx (accessed 15.05.2020).

Janota J. (1958a), Walka o punkty w strzelaniu z broni matokalibrowej, "Kultura Fizyczna”, no. 1, pp. $111-119$.

Janota J. (1958b), Metody treningu z broni matokalibrowej dokładnej w pracach dawnych $i$ wspótczesnych autorów, "Kultura Fizyczna", no. 2, pp. 16-22.

Kalesan B., Villarreal M.D., Keyes K.M., Galea S. (2017), Gun Ownership and Social Gun Culture, "Injury Prevention", vol. 22(3), pp. 216-220.

Kijowski A. (2013), Kontrola procesu treningowego w strzelectwie sportowym, "Strzelectwo sportowe (Nowoczesne rozwiązania szkoleniowe)", no. 10, Wrocław, pp. 19-28.

Krawczyk Z. (2011), Powstanie i rozwój socjologii kultury fizycznej, [in:] Z. Dziubiński, Z. Krawczyk (eds.), Socjologia kultury fizycznej, Wydawnictwo Akademii Wychowania Fizycznego, Warszawa.

Kurzawski K. (2009), Skuteczny trener strzelectwa sportowego, "Strzelectwo sportowe (Nowoczesne rozwiązania szkoleniowe)", no. 6, Wrocław.

Kurzawski K. (2010), Kompetencje zawodowe trenera strzelectwa sportowego, "Strzelectwo sportowe (Nowoczesne rozwiązania szkoleniowe)", no. 7, Wrocław.

Kurzawski K., Filipkowski S. (2007), Praca trenera strzelectwa sportowego, "Strzelectwo sportowe (Nowoczesne rozwiązania szkoleniowe)", no. 4, Wrocław.

Lewiecki E.M., Miller S.A. (2013), Suicide, Guns, and Public Policy, "American Journal of Public Health", vol. 103(1), pp. 27-31.

Lott J.R. (2013), More Guns, Less Crime: Understanding Crime and Gun Control Laws, The University of Chicago Press, Chicago-London.

Martin J. (2012), The Transformation of Lowland Game Shooting in England and Wales in the Twentieth Century: The Neglected Metamorphosis, "The International Journal of the History of Sport", vol. 29(8), pp. 1141-1158. 
Matuszak A. (1951), Strzelectwo sportowe na spartakiadzie, "Kultura Fizyczna”, no. 10, p. 628. Matuszak A. (1952), Istota sportu strzeleckiego, "Kultura Fizyczna", no. 7, pp. 534-539.

Matuszak A. (1957), Strzelanie z postawy stojacej z broni małokalibrowej, "Kultura Fizyczna", no. 1 , pp. 31-37.

Mauer-Różańska R. (2018), Zmiany jakości w ekspozycji widowisk w strzelectwie sportowym, "Strzelectwo sportowe (Nowoczesne rozwiązania szkoleniowe)", no. 15, Wrocław.

Naglak Z., Zarzycki J. (1976), Poziom ogólnej sprawności fizycznej a wyniki w strzelectwie sportowym, "Kultura Fizyczna", no. 5, pp. 211-214.

Najwyższa Izba Kontroli (NIK) (2017), Utrzymanie przez gminy obiektów wybudowanych wramach programu "Moje boisko - Orlik 2012", https://www.nik.gov.pl/plik/id,16647,vp,19200. pdf, p. 5 (accessed 15.05.2020).

Podowski J. (2019), Podręczniki strzeleckie, Napoleon V, Oświęcim.

Polski Związek Strzelectwa Sportowego (PZSS) (2020), Medaliści olimpijscy, https:// www.pzss.org.pl/medalisci (accessed 15.05.2020).

Skrzypiec-Spring M., Spring A., Skrzypiec D. (2009), Narażenie na hałas w strzelectwie sportowym, "Strzelectwo sportowe (Nowoczesne rozwiązania szkoleniowe)", no. 6, Wrocław, pp. 59-62.

Strauss A.L. (1978), A Social Worlds Perspective, [in:] N. Denzin (ed.), Studies in Symbolic Interaction 4, JAI Press, Greenwich.

Strauss A.L. (1993), Continual Permutations of Action, Routledge, New York.

Strauss A.L. (2013), Zwierciadła i maski. W poszukiwaniu tożsamości, transl. A. Hałas, Zakład Wydawniczy NOMOS, Kraków.

Szewczyk J. (1965), Nowe problemy sportu i wychowania fizycznego w wojsku, "Kultura Fizyczna", no. 9, p. 500.

Weber M. (1998), Polityka jako zawód i powołanie, transl. A. Kopacki, P. Dybel, Społeczny Instytut Wydawniczy Znak, Fundacja im. Stefana Batorego, Kraków-Warszawa.

Wodnik J. (2007), Przygotowanie fizyczne w treningu strzelca, "Strzelectwo sportowe (Nowoczesne rozwiązania szkoleniowe)", no. 4, pp. 151-154.

Wohl A. (1965), Pojęcie i zakres socjologii sportu, "Kultura Fizyczna”, no. 3, pp. 140-141.

Zgorski A., Tkaczuk W. (2005), Przyczyny urazów kręgostupa u osób wyczynowo uprawiajacych strzelectwo sportowe i tucznictwo, "Pedagogics, Psychology, Medical-Biological Problems of Physical Training and Sport", no. 18, pp. 99-107.

\title{
CZY STRZELECTWO JEST SPORTEM? ZARYS PROBLEMATYKI STRZELECTWA SPORTOWEGO W POLSCE JAKO PRZEDMIOTU SOCJOLOGII SPORTU
}

\begin{abstract}
Abstrakt. Głównym celem tego tekstu jest odpowiedź na pytanie, czy strzelectwo sportowe należy traktować jako sport, oraz przekonanie czytelników, że strzelectwo może być interesującym przedmiotem socjologii sportu. Strzelectwo sportowe to dynamicznie rozwijająca się aktywność, która w ostatnich latach angażuje w Polsce coraz więcej osób. Artykuł przedstawia historię i specyfikę tej dyscypliny sportu, w tym prezentuje dyscypliny sportowe oraz klasyfikację osób uczestniczących w świecie społecznym strzelców. Tekst zawiera również wstępne wnioski dotyczące zjawisk społecznych dotyczących środowiska strzeleckiego oraz rozważania metodologiczne związane $\mathrm{z}$ barierami występującymi w badaniach tego środowiska.
\end{abstract}

Słowa kluczowe: strzelectwo sportowe, broń palna, światy społeczne, praktyki społeczne, etnografia. 